\title{
Short Review on the Use of Oil Palm Shell in Concrete and Activated Carbon
}

\author{
Soonmin Ho $^{1^{*}}$, Md Munir Hayet Khan ${ }^{2}$ \\ ${ }^{1}$ Centre for American Education, INTI International University, Putra Nilai, Negeri Sembilan, Malaysia \\ ${ }^{2}$ Faculty of Engineering and Quantity Surveying, INTI International University, Putra Nilai, Negeri Sembilan, Malaysia \\ Email: *soonmin.ho@newinti.edu.my
}

How to cite this paper: Ho, S.M. and Khan, M.M.H. (2020) Short Review on the Use of Oil Palm Shell in Concrete and Activated Carbon. World Journal of Nano Science and Engineering, 10, 1-13.

https://doi.org/10.4236/wjnse.2020.101001

Received: January 15, 2020

Accepted: March 1, 2020

Published: March 4, 2020

Copyright (c) 2020 by author(s) and Scientific Research Publishing Inc. This work is licensed under the Creative Commons Attribution International License (CC BY 4.0).

http://creativecommons.org/licenses/by/4.0/

(c) (i) Open Access

\begin{abstract}
Oil palm is known as Elaeis guineensis, found in Africa, South East Asia and China. Oil palm shell is used to prepare activated carbon because of high carbon content, high surface area, highly developed porosity and low price. During the physical activation, carbonization occurs in order to create porosity in the raw material. Literature review indicated that carbon material was impregnated with chemical agents such as phosphoric acid, potassium hydroxide, sulphuric acid, sodium hydroxide and zinc chloride in chemical activation process. Experimental results showed that the obtained activated carbon was used in hydrogen storage purpose, supercapacitor, gases and liquid phase adsorption process. On the other hand, oil palm shell was used in manufacturing lightweight concrete because of lighter and will not produce toxic substance. The bulk density and compressive strength of oil palm shell-based concrete were 500 - 600 $\mathrm{kg} / \mathrm{m}^{3}$ and more than $25 \mathrm{MPa}$, respectively.
\end{abstract}

\section{Keywords}

Activated Carbon, Oil Palm Shell, Concrete, Activation, Carbonization

\section{Introduction}

The United States Department of Agriculture estimated Malaysia's 2019 palm oil production was at 20.5 million metric tons [1], up 4 percent from year 2018 and it is the second prime palm oil producing country in the world. In a study, it predicted to increase every year involving 4.4 million hectares of cultivating area [2]. Palm oil mills produce crude palm oil and oil palm kernel as well as vast quantities of remains such as oil palm fibre, shell and empty fruit bunches [3]. Such as 19 million tonnes' crop residues contain empty fruit bunch, fibre and shell from per year of production [2]. It is projected that more than 4.56 million 
tonnes of palm shell as left-over is generated yearly [4]. And this is just oil palm shell (OPS) causing from handling of palm oil production which interjects 5.5\% to the overall solid waste. Thus, using OPS as an aggregate can be considered as ecologically desirable in order to fully utilize waste materials appearing as byproducts from other industries [5]. In operation of turbines for electricity OPS has been customarily used as solid fuels for steam boiler [6] and to envelop the surface of the roads in the areas where it is planted [7]. It was also converted to bio-oil through pyrolysis process for energy [8] and densified into briquettes. It was also used in the production of charcoal and activated carbon. Researchers have been investigating the capability of OPS as structural lightweight aggregate for more than twenty years. Among the countries in the world, Indonesia, Malaysia Thailand and Nigeria have oil palm industry as one of their main agricultural based industry. Yearly production of the crude palm oil by Malaysia is over 7 million tonnes [9]. Palm oil production over the world is shown in Figure 1.

One of the major downsides of this process is the amount of solid waste generated during the palm fruit processing. For example, Malaysia, Indonesia, Thailand and Nigeria produce over 8 million tons of oil palm shell (OPS) in a year [11].

In construction of building load bearing ability such as dead load is vital in design stages. Lightweight concrete is normally exercised to solve this problem. Two main advantages designers may expect while applying lightweight aggregate concrete: reduced dead load weight and high thermal insulation, both are important in minimizing earthquake impact. In lightweight concrete, functional design and architectural expression of forms can be achieved easier than in any other avenue [12]. Currently, architects, contractors and engineers have recognized the essential financial side and associated gains offered by lightweight concrete. Nevertheless, different features of lightweight aggregate and concrete required departures from ordinary practice to suit the purpose of design [13]. Such as, lightweight aggregate concrete can be used as part of a building structure

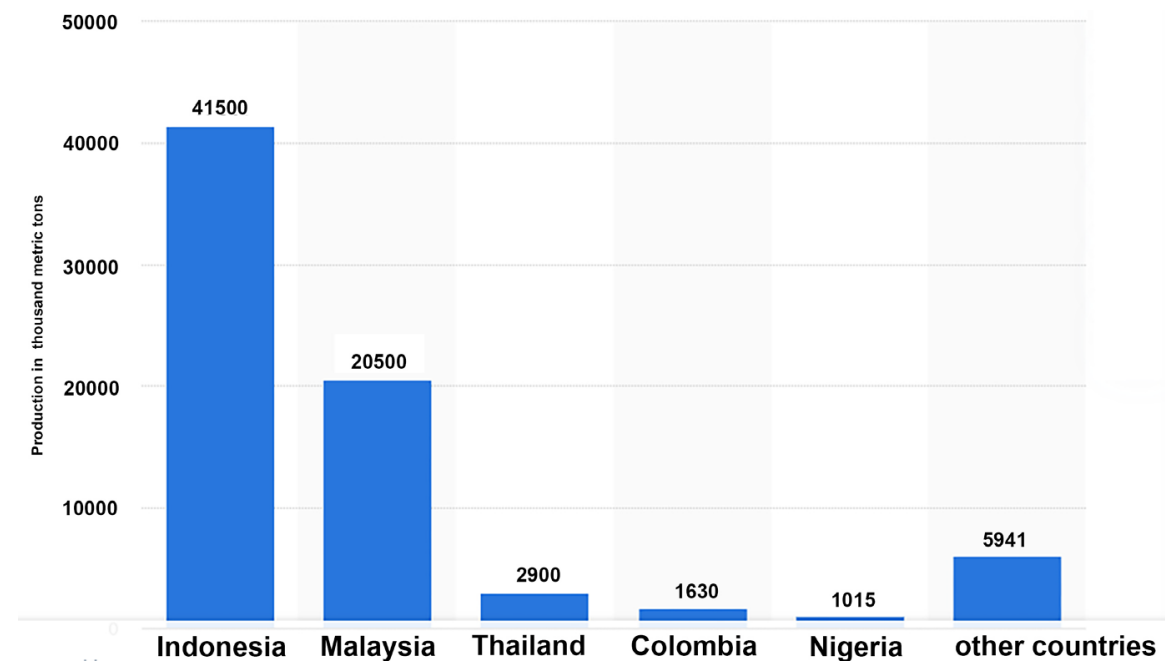

Figure 1. Leading producers of palm oil worldwide from 2018/2019 [10]. 
in slab, wall and column. And in its creation, the employment and reutilizing of solid waste material especially from agro-industry are very meaningful [6]. Replacement of agricultural wastes and industry based wastes into worthwhile materials has not only eco-friendly benefits, but may also safeguard the natural resources. Agricultural waste materials have good possibility or benefit to be generated back to advantageous material, suitably decreasing problems related to solid waste instead of only reducing the waste production.

Activated carbon has very unique properties such as high surface area and high porosity, which increases adsorption capacity. Porous materials [14] could be divided into three categories (Figure 2), namely microporous (less than $2 \mathrm{~nm}$ ), mesoporous (2 - $50 \mathrm{~nm}$ ) and macroporous (greater than $50 \mathrm{~nm}$ ). Activated carbon could be produced by using several raw materials including watermelon peel [15], banana peel [16], orange peel [17], lemon peel [18], tea [19], coconut shell [20], waste tire rubber [21], durian shell [22], rambutan [23], pine cone [24], grape [25], papaya seed [26], mango [27] under physical or chemical activation process. As reported, global activated carbon market size about USD 4.72 billion in 2018 [28] due to increasing demand in water treatment, food processing air and gas purification applications [29]. Oil palm shell was used to prepare activated carbon due to high carbon content, high surface area, highly developed porosity and low price. It is known as Elaeis guineensis, found in Africa, South East Asia and China. Palm oil and palm kernel oil were produced from oil palm fruit. Palm oil was used in candle, soap, cosmetic, biofuel and lubricating greases while palm kernel oil was employed in ice cream, margarine, bread, chocolate.

In this work, oil palm shell was used to prepare activated carbon and concrete. The obtained activated carbon was employed in wide applications as discussed here. The properties of oil palm based concrete were explained and compared with other raw materials well.

\section{Literature Survey}

\subsection{Oil Palm Based Concrete}

Oil palm shell (OPS) is not frequently consumed in the building construction industry but is regularly curbed as wastes generated from agricultural bases [30].

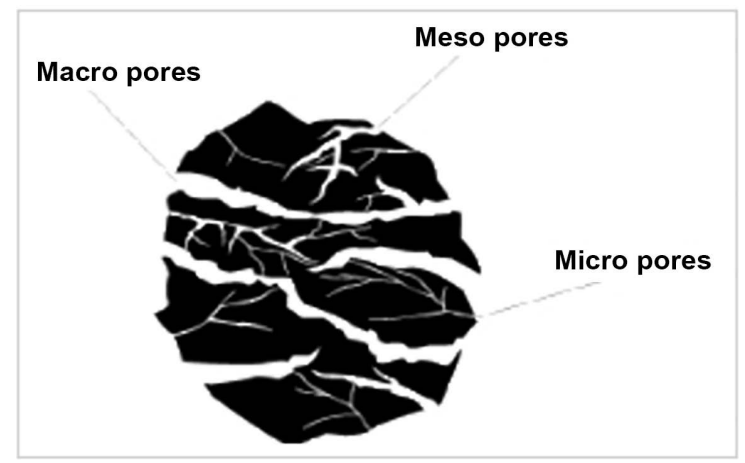

Figure 2. Three groups of pores are distinguished based on IUPAC definitions. 
Numerous proposals focusing on minimizing traditional building material costs have been deliberated by using such kind of agro-wastes with the pursuit of affordable housing system for both the rural and urban populations of Malaysia and other developing countries. In countries where abundant agricultural wastes are discharged, these wastes can be used as potential replacement material in construction industry [31] [32]. One such choice is OPS which has the prospective to be used as substitute coarse aggregate in concrete [13]. Oil palm solid wastes are produced in abundant in the factories and is mostly burned by the orthodox process and it contributes to air pollution [33]. Consequently, these remainders are becoming costly to fix by fulfilling the requirements of environmental regulations imposed by Department of Environment. Efforts are underway to improve the use of these by-products through the development of various products with added values. One of the alternatives to dispose these wastes would be the consumption of palm shell (OPS) into building materials. Green issues are becoming more important at this age and needs to be addressed in all possible aspects of life, therefore the buildings are not exempted. On the other hand, construction materials have significant impacts on the Green Building Rating (GBR). Three of the vital factors to be mentioned which make concrete less eco-friendly are: a) carbon monoxide emission during the process of cement production, b) the amount of energy we offer to it, c) natural resources used such as water, aggregate and fillers are extensively used in the creation process of concrete.

Lately a number of researches [32] [34] have been conducted to utilize these palm shell wastes in manufacturing lightweight concrete. OPS are the hard stony endocarp but are lightweight and naturally sized. Once they adjoin in the concrete matrix, they will not infect or percolate to produce toxic substances due to the rigid surfaces of organic origin. In addition, OPS are lighter than the conventional coarse aggregate so the resulting concrete will be lightweight [35]. OPS replacement coarse aggregate is able to attain the strength of more than $17 \mathrm{MPa}$ [34], which is a necessity for structural lightweight concrete as per ASTM (ASTM C330). Lately, OPS concrete compressive strength has attained more than $25 \mathrm{MPa}$ [36]. The bulk density of OPS is in the range of $500-600 \mathrm{~kg} / \mathrm{m}^{3}$ [6]. It was noticed that partial replacement OPS concrete density varies in the range of 1700 to $2185 \mathrm{~kg} / \mathrm{m}^{3}$. Thus, it can be used as a better replacement of coarse aggregate to generate structural lightweight concrete. To realise the potential of OPS in concrete applications, Harimi and co-workers [37], who has evaluated the daily normal temperature of house wall surface by using OPS based lightweight concrete as building material, informed that OPS concrete walls temperature was always lower than the outdoor temperature. Nevertheless, the study only evaluated the interior surface temperature of the wall and concentrated on the architectural aspect. Even though OPS lightweight aggregate concrete has been effectively made in the past, most of the researchers focused on structural lightweight concrete purpose and the highest 28-day compressive strength of about $48 \mathrm{MPa}$ [38]. Previous studies have used only around $15 \%$ to $18 \%$ OPS of volume fraction from total volume of OPS based lightweight concrete to produce high compres- 
sive strength. OPS concrete seems to be inexpensive compared to the normal aggregate concrete. The shape of OPS shape can be angular or polygonal based on the breaking arrangement of the nut and its oil color differs. The attributes of the OPS are such that the OPS has the density identical to the other lightweight aggregates whereas its weight is about $60 \%$ less as measured against the usual coarse aggregates [39] [40] [41]. Furthermore, OPS have Los Angeles abrasion value about $1 / 5^{\text {th }}$ of normal coarse aggregates [42]. Consequently, such characters and properties make OPS aggregates endurance to wear and low impact and crushing values makes them compatible to shockwave [4]. Shell thickness of OPS too is similar to coconut shell and flakiness index is about three times higher than crushed granite [39].

\subsection{Oil Palm Shell Based Activated Carbon}

The preparation of activated carbon under different physical and chemical activation conditions was reported by many researchers. Researchers have observed that porosity of charcoal could be developed under carbonization stage. Selection of lower or higher carbonization temperature causes a significant effect on the samples. Basically, there are two groups of activation process, namely physical activation [under steam and carbon dioxide] and chemical activation [phosphoric acid, $\mathrm{K}_{2} \mathrm{CO}_{3}, \mathrm{KOH}, \mathrm{ZnCl}_{2}$, sulphuric acid]. This process plays an important role in order to enlarge pore volume, diameter of pores and porosity of activated carbon [43]. Table 1 shows the activated carbon has been successfully produced by using various raw materials under physical and chemical activation. Highlighted results were provided based on literature review.

In this work, activated carbon produced by using oil palm shell as raw material. Activated carbons obtained could be used for hydrogen storage purpose. Because of theses carbons have many advantages including high surface area, inexpensive materials, highly pore microstructure, light weight and stable for large scale production. Zhao and co-workers [55] reported that the produced carbons have surface area of $3508 \mathrm{~m}^{2} / \mathrm{g}$, micropores volume of $1.1 \mathrm{~cm}^{3} / \mathrm{g}$. Outstanding storage capacities of hydrogen were $6.8 \%$ and $2.86 \%$ at $4 \mathrm{MPa}$ and 1 bar respectively.

On the other hand, removal of copper ions by using activated carbon was studied. Gulnaziya and co-workers [56] found that high adsorption capacity at $\mathrm{pH}$ 5 if compared to $\mathrm{pH} 3$ and in the presence of complexing agent such as malonic acid, boric acid. Other researchers such as Muzakkir and co-workers [57] study removal of zinc ion, lead ion and copper ions by using activated carbon. The best conditions such as $\mathrm{pH}(\mathrm{pH}$ 6), absorbent dosage $(0.5 \mathrm{~g})$ and contact time (45 minutes). Good removal of lead ion (100\%) if compared to zinc (79\%) and copper ion (81\%). The best kinetic model is pseudo-second order model. Removal of chromium ions by using chitosan coated activated carbon was reported by Saifuddin and co-workers [58]. Adsorption capacity was $154 \mathrm{mg} \mathrm{Cr} / \mathrm{g}$ and fittest well Langmuir model. 
Table 1. Production of activated carbon and highlighted results.

\begin{tabular}{|c|c|c|c|}
\hline Raw material & Physical activation & Chemical activation & Highlighted results \\
\hline Palm tree branches & $\begin{array}{l}\text { - } 700^{\circ} \mathrm{C} \text { for } 1 \text { hour } \\
\text { under steam }\end{array}$ & $\begin{array}{l}\text { - At } 500^{\circ} \mathrm{C} \text { for } 2 \text { hours } \\
\text { - Activating agent: } \\
\text { Phosphoric acid and } \mathrm{K}_{2} \mathrm{CO}_{3}\end{array}$ & $\begin{array}{l}\text { - SEM: The highest development of pores could be } \\
\text { observed as the concentration of phosphoric acid was } \\
\text { increased [44]. } \\
\text { pH: The highest percentage removal of } \mathrm{Cr} \text { (VI) ions was } \\
\text { observed at pH } 2 \text {. }\end{array}$ \\
\hline Olive wastes & $\begin{array}{l}573 \mathrm{~K} \text { for } 3 \text { hours } \\
\text { under steam }\end{array}$ & $\begin{array}{l}\text { - } 1073 \mathrm{~K} \text { for } 1 \text { hour } \\
\text { Activation agent: Phosphoric } \\
\text { acid and potassium hydroxide }\end{array}$ & $\begin{array}{l}\text { BET: } 1375 \mathrm{~m}^{2} / \mathrm{g} \text { and } 466 \mathrm{~m}^{2} / \mathrm{g} \text { for the activated carbon } \\
\text { impregnated with } \mathrm{KOH} \text { and phosphoric acid, } \\
\text { respectively [45]. } \\
\text { Activated carbon impregnated with KOH has the } \\
\text { highest micropore volume }\left(0.52 \mathrm{~m}^{3} / \mathrm{g}\right) \text {, mesopore } \\
\text { volume }\left(0.3 \mathrm{~cm}^{3} / \mathrm{g}\right) \text { if compared to phosphoric acid. } \\
\text { - Adsorption of indigo carmine supported Freundlich } \\
\text { model, and pseudo-second order kinetic equation. }\end{array}$ \\
\hline Oak sawdust & - $500^{\circ} \mathrm{C}$ for 5 minutes & $\begin{array}{l}\text { - } 500^{\circ} \mathrm{C} \text { for } 35 \text { minutes } \\
\text { - Phosphoric acid }\end{array}$ & $\begin{array}{l}\text { - Carbon yield ( } 29.4 \%) \text {, moisture content }(4.6 \%) \text { and ash } \\
\text { content (6.6\%) for the activated carbon impregnated } \\
\text { with phosphoric acid were reported [ } 46] \text {. } \\
\text { The Langmuir adsorption of phenol }(99 \mathrm{mg} / \mathrm{g}) \text { and } \\
\text { nicotinic acid }(99 \mathrm{mg} / \mathrm{g}) \text { for the activated carbon } \\
\text { impregnated with phosphoric acid was highlighted. }\end{array}$ \\
\hline
\end{tabular}

- The highest carbon content could be observed for the activated carbon prepared at $850^{\circ} \mathrm{C}(80.46 \%)$ if compared to $650^{\circ} \mathrm{C}(66.18 \%)$ and $750^{\circ} \mathrm{C}(70.92 \%)$.

Rice straw $\quad-400^{\circ} \mathrm{C}$ for 4 hours temperature $\left(650^{\circ} \mathrm{C}, 750^{\circ} \mathrm{C}\right.$ and $\left.850^{\circ} \mathrm{C}\right)$

- $\mathrm{KOH}$
- The highest surface area $\left(1048 \mathrm{~m}^{2} / \mathrm{g}\right)$, total pore volume $\left(0.64 \mathrm{~cm}^{3} / \mathrm{g}\right)$, micropore volume $\left(0.0436 \mathrm{~cm}^{3} / \mathrm{g}\right)$ and mesopore $\left(0.568 \mathrm{~cm}^{3} / \mathrm{g}\right)$ could be seen in activated carbon produced at $850^{\circ} \mathrm{C}$ [47].
Prawn shell - $800^{\circ} \mathrm{C}$ for 3 hours
- $800^{\circ} \mathrm{C}$ for 1 hour

- $\mathrm{KOH}$

- Activated carbon impregnated with $\mathrm{KOH}$ showed the highest surface area $\left(3160 \mathrm{~m}^{2} / \mathrm{g}\right)$ and pore volume $\left(2.38 \mathrm{~cm}^{3} / \mathrm{g}\right)$.

- XRD: Data supported activated carbon impregnated with $\mathrm{KOH}$ has disorder carbon structure and crystallite layer if compared to carbonized sample [48].

- The obtained activated carbon can remove $\mathrm{Cu}^{2+}, \mathrm{Cr}^{6+}$ and $\mathrm{Cd}^{2+}$ ions.

- Adsorption capacity of methylene blue was increased with contact time $(6,24$ hours), adsorbent dosage ( 0.5 to $1.5 \mathrm{~g}$ ) and initial concentration ( 1 to $2 \mathrm{mg} / \mathrm{L}$ ) [49].

- BET surface area and micropore volume strongly depended on the concentration of zinc chloride such as $20 \%\left(1121 \mathrm{~m}^{2} / \mathrm{g}, 0.22 \mathrm{~cm}^{3} / \mathrm{g}\right), 30 \%\left(1588 \mathrm{~m}^{2} / \mathrm{g}, 0.08\right.$ $\left.\mathrm{cm}^{3} / \mathrm{g}\right)$ and $40 \%\left(1404 \mathrm{~m}^{2} / \mathrm{g}, 0.01 \mathrm{~cm}^{3} / \mathrm{g}\right)$ [50].

Elaeagnus stone $\quad \cdot 600^{\circ} \mathrm{C}$ for 6 hours $\quad \cdot \mathrm{ZnCl}_{2}$

- Removal of rhodamine B, methylene blue, malachite green fitted with Langmuir isotherm and pseudo second order kinetic model. 


\begin{tabular}{|c|c|c|c|}
\hline Green coconut shell & - $650^{\circ} \mathrm{C}$ for 1 hour & - $\mathrm{ZnCl}_{2}$ & $\begin{array}{l}\text { Volatile matter }(17.2 \%) \text {, fixed carbon }(78.9 \%) \text {, ash } \\
\text { content }(0.9 \%) \text {, surface area }\left(995 \mathrm{~m}^{2} / \mathrm{g}\right) \text {, micropore } \\
\text { volume }\left(0.37 \mathrm{~cm}^{3} / \mathrm{g}\right) \text { in the obtained activated carbon } \\
\text { were reported [51]. } \\
\text { - Removal of methylene blue greater than } 90 \% \text { when the } \\
\text { contact time about } 9 \text { - } 10 \text { hours. }\end{array}$ \\
\hline $\begin{array}{l}\text { Apple pulp and } \\
\text { apple peel }\end{array}$ & $\begin{array}{l}\text { Modified microwave } \\
\text { oven was used }\end{array}$ & $\begin{array}{l}\text { - Furnace was used during the } \\
\text { activation process. } \\
\text { - Activation agent: phosphoric } \\
\text { acid }\end{array}$ & $\begin{array}{l}\text { - The highest removal of methylene blue was } 94.6 \% \text { and } \\
87.2 \% \text { for pulp-based, and peel-based activated carbon } \\
\text { [52]. } \\
\text { BET surface area showed the highest value }\left(1552 \mathrm{~m}^{2} / \mathrm{g}\right) \\
\text { in apple peel based activated carbon if compared to } \\
\text { pulp based }\left(1103 \mathrm{~m}^{2} / \mathrm{g}\right) \text {. }\end{array}$ \\
\hline Orange peel & $\begin{array}{l}\text { Tubular furnace was } \\
\text { used, } 1073 \mathrm{~K} \text { for } 1 \\
\text { hour }\end{array}$ & • -- & $\begin{array}{l}\text { - Removal of phenol onto activated carbon was } 88 \mathrm{mg} / \mathrm{g} \\
\text { when the contact time is } 3 \text { hours [53] } \\
\text { - The adsorption data support pseudo second order } \\
\text { model. } \\
\text { - The best pH values are in the range of } 4 \text { to } 8 \text {. }\end{array}$ \\
\hline Banana peel waste & - $350^{\circ} \mathrm{C}$ for 1 hour & - Sulphuric acid & $\begin{array}{l}\text { - The highest iodine number could be observed when } \\
\mathrm{H}_{2} \mathrm{SO}_{4} \text { was used during the activation process [54]. } \\
\text { - Percentage of yield increased from } 33.56 \% \text { to } 61.4 \% \text { as } \\
\text { concentration of } \mathrm{H}_{2} \mathrm{SO}_{4} \text { decreased from } 6 \mathrm{~N} \text { to } 1 \mathrm{~N} \text {. } \\
\text { - BET surface area increased from } 367 \text { to } 426 \mathrm{~m}^{2} / \mathrm{g} \text { with } \\
\text { increasing the concentration of sulfuric acid. }\end{array}$ \\
\hline
\end{tabular}

The adsorption of carboxylic acid formed during fermentation has been investigated by Hector and co-workers [59]. The adsorption data revealed that higher adsorption capacities could be observed in basic medium (potassium hydroxide) if compared to acid medium (phosphoric acid). Because of more favorable superficial chemistry and higher development of porosity.

Lua and Guo [60] reported the use of activated carbon for gas $\left(\mathrm{SO}_{2}\right.$ gas) phase adsorption. The experimental data supported linear relationship between surface area, porosity and adsorptive capacity. Purification of hydrogen from hydrogen-methane gas mixture was carried out by Sheila and co-workers [61] using activated carbon. The maximum adsorption capacity of pure methane could be observed at $20^{\circ} \mathrm{C}$, following by mixture gas of $\mathrm{CH}_{4} / \mathrm{H}_{2}$ and pure hydrogen. The adsorption data support the Langmuir model. Arash and co-workers [62] prepared activated carbon under various concentrations of zinc chloride. They found that large volume of micropores in carbon. They conclude that $100 \%$ net increase in the methane capacity under carbon dioxide if compared to a flow of nitrogen.

Izan and co-workers [63] highlighted that activated carbon was used in supercapacitor electrode application. During the experiment, there are several aqueous electrolytes were provided. Results showed that achievable operating potential values were $1 \mathrm{~V}, 1.2 \mathrm{~V}$ and $2 \mathrm{~V}$ for sulfuric acid, potassium hydroxide and $\mathrm{Na}_{2} \mathrm{SO}_{4}$ electrolyte, respectively. The highest energy densities about $7.4 \mathrm{Wh} / \mathrm{kg}$ for the sample 
Table 2. Advantages and disadvantages of activated carbon adsorption.

\begin{tabular}{cc}
\hline Advantage & Disadvantage \\
\hline Low cost-raw material & Cannot remove dust and pollen \\
Simple technology & Possible impurities can leach into a liquid \\
High removal capacity for organic component & Nonselective removal for certain molecules \\
Reuse & \\
Purify large volume of gas or liquid & \\
\hline
\end{tabular}

prepared in $\mathrm{Na}_{2} \mathrm{SO}_{4}$ electrolyte. Hendriansyah and co-workers [64] highlighted that the obtained carbon has capacitance of $1.75 \mathrm{~F} / \mathrm{g}$. General physical properties such as surface area $\left(8-451 \mathrm{~m}^{2} / \mathrm{g}\right)$, pore volume $\left(0.05-1.06 \mathrm{~cm}^{3} / \mathrm{g}\right)$ and pore size $(2.9$ to $20.7 \mathrm{~nm}$ ) were reported. During the experiment, working electrode and second electrode are activated carbon and nickel oxide, respectively.

Basic dye adsorption such as methylene blue was investigated by using oil palm shell based activated carbon. The adsorption data supported the pseudo-second order model in untreated and HCL-treated activated carbon [65]. The equilibrium data revealed that higher adsorption capacity $(303 \mathrm{mg} / \mathrm{g})$ was observed in $\mathrm{HCl}$-treated carbon. Thermodynamic data showed endothermic in nature. Mook and co-worker [66] reported that activated carbon produced from palm shell. The obtained carbon showed surface area of $759 \mathrm{~m}^{2} / \mathrm{g}$, average pore diameter of $4.96 \mathrm{~nm}$, micro pore volume of $0.299 \mathrm{~cm}^{3} / \mathrm{g}$. The dye removal efficiency increased with increasing adsorbent dose from 2 to $10 \mathrm{~g} / \mathrm{L}$, temperature from $18^{\circ} \mathrm{C}$ to $38^{\circ} \mathrm{C}$, decreasing $\mathrm{pH}$ from $\mathrm{pH} 11$ to 2 . Experimental results revealed that reactive black 5 adsorptions were endothermic, supported Langmuir model, and fitted pseudo-first order model.

Experimental results showed that activated carbon was made from oil palm shell under physical and chemical activation process. The obtained activated carbon was used in hydrogen storage, super capacitor electrode application, gas and liquid phase adsorption. Table 2 indicated the advantage and disadvantage of activated carbon adsorption.

\section{Conclusion}

Currently, Malaysia ranked as second largest palm oil producer in the world. Generally, producer in the country is grouped into private, smallholder and joint venture. The primary importing countries: such as China, Pakistan, United States and European Union. Oil palm shell has many applications as highlighted in paper. Oil palm shell based activated carbon could be used as adsorbent to remove pollutant in waste water and gas phase adsorption. Activated carbon produced by using these raw materials has high surface area, high adsorptive capacities. Other findings showed that oil palm shell has potential to be employed in concrete. Oil palm shell is the hard stony endocarp but is lightweight and naturally sized. It could be used as a good replacement of coarse aggregate. 


\section{Acknowledgements}

The authors gratefully acknowledge the financial support provided by the INTI International University.

\section{Conflicts of Interest}

The authors declare no conflicts of interest regarding the publication of this paper.

\section{References}

[1] https://ipad.fas.usda.gov/highlights/2019/05/malaysia/index.pdf

[2] Mustaffa, W.E.S.B., Mehilef, S., Saidur, R. and Safari, A. (2011) Biomass Energy in Malaysia: Current State and Prospects. Renewable \& Sustainable Energy Review, 15, 3360-3370. https://doi.org/10.1016/j.rser.2011.04.016

[3] Abdullah, A.A.A. (1996) Palm Oil Shell Aggregate for Lightweight Concrete. In: Waste Material Used in Concrete Manufacturing, Elsevier, Amsterdam, 624-636. https://doi.org/10.1016/B978-081551393-3.50013-2

[4] Teo, D.C.L., Mannan, M.A. and Kurian, J.V. (2006) Flexural Behaviour of Reinforced Lightweight Concrete Beams Made with Oil Palm Shell (OPS). Journal of Advanced Concrete Technology, 4, 1-10. https://doi.org/10.3151/jact.4.459

[5] Pankhurst, R.N.W. (1993) Structural Lightweight Aggregate Concrete, Chapter 4, Construction. Chapman \& Hall, London.

[6] Shafigh, P., Jumaat, M.Z. and Mahmud, H. (2010) Mix Design and Mechanical Properties of Oil Palm Shell Lightweight Aggregate Concrete: A Review. International Journal of the Physical Sciences, 5, 2127-2134.

[7] Abdullahi, M., Al-Mattarneh, H.M.A., Hassan, A.H.A., Hassan, M.H. and Mohammed, B.S. (2008) Trial Mix Design Methodology for Palm Oil Clinker (POC) Concrete. The International Conference on Construction and Building Technology in Kuala Lumpur, Kuala Lumpur, Malaysia, June 2008.

[8] Sahu, J.N., Abnisa, F., Daud, W.M.A. and Husin, W.M.W. (2011) Utilization Possibilities of Palm Shell as a Source of Biomass Energy in Malaysia by Producing Bio-Oil in Pyrolysis Process. Biomass and Bioenergy, 35, 1863-1872. https://doi.org/10.1016/j.biombioe.2011.01.033

[9] Miura, K., Masuda, T., Funazukuri, T., Sugawara, K., Shirai, Y., Hayashi, J.-I., Karim, M.I.A., Ani, F.N. and Susanto, H. (2001) Efficient Use of Oil Palm Wastes as Renewable Resource for Energy and Chemicals. Kyoto University, Japan.

[10] https://www.statista.com/statistics/856231/palm-oil-top-global-producers/

[11] Alireza, J.P., Salleh, S., Payam, S. and Hilmi, B.M. (2016) Toward Sustainability in Concrete Industry by Using of Solid Wastes from Palm Oil Industry. MATEC Web of Conferences, 66, Article ID: 600099. https://doi.org/10.1051/matecconf/20166600099

[12] Mannan, M.A. and Ganapathy, C. (2002) Engineering Properties of Concrete with Oil Palm Shell as Coarse Aggregate. Construction and Building Materials, 16, 29-34. https://doi.org/10.1016/S0950-0618(01)00030-7

[13] Teo, D., Mannan, M.A., Kurian, V. and Ganapathy, C. (2007) Lightweight Concrete Made from Oil Palm Shell (OPS): Structural Bond and Durability Properties. Building and Environment, 42, 2614-2621. https://doi.org/10.1016/j.buildenv.2006.06.013

[14] http://sujatacarbons.com/activated-carbon.html 
[15] Gin, W.A., Jimoh, A., Giwa, A. and Abdulkareem, A.S. (2014) Production of Activated Carbon from Watermelon Peel. International Journal of Scientific \& Engineering Research, 5, 66-71.

[16] Olaoye, R.A., Afolayan, O.D., Mustapha, O.I. and Adeleke, H.G. (2018) The Efficacy of Banana Peel Activated Carbon in the Removal of Cyanide and Selected Metals from Cassava Processing Wastewater. Advances in Research, 16, 1-12. https://doi.org/10.9734/AIR/2018/43070

[17] Aarthi, P., Ramakrishnan, K., Sudharshan, V. and Subramanyan, V. (2018) OPAC (Orange Peel Activated Carbon) Derived from Waste Orange Peel for the Adsorption of Chlorophenoxyacetic Acid Herbicides from Water: Adsorption Isotherm, Kinetic Modelling and Thermodynamic Studies. Bioresource Technology, 261, 329-341. https://doi.org/10.1016/j.biortech.2018.04.005

[18] Maryam, Q., Lahieb, F., Zainab, T. and Talib, A. (2018) Possibility of Utilizing from Lemon Peel as a Sorbent in Removing of Contaminant Such as Copper Ions from Simulated Aqueous Solution. International Journal of Civil Engineering and Technology, 9, 571-579.

[19] Auta, M. and Hameed, B.H. (2011) Optimized Waste Tea Activated Carbon for Adsorption of Methylene Blue and Acid Blue 29 Dyes Using Response Surface Methodology. Chemical Engineering Journal, 175, 233-243.

https://doi.org/10.1016/j.cej.2011.09.100

[20] Iqbaldin, M.N., Khudzir, I., Azlan, M.I., Zaidi, A.G., Surani, B. and Zubri, Z. (2013) Properties of Coconut Shell Activated Carbon. Journal of Tropical Forest Science, 25, 497-503.

[21] Manju, S.K., Vinod, K. and Vinay, K.J. (2016) Preparation of Activated Carbon from Waste Tire Rubber for the Active Removal of Cr(VI) and Mn(II) Ions from Aqueous Solution. Transactions of the Indian Ceramic Society, 75, 234-241. https://doi.org/10.1080/0371750X.2016.1228481

[22] Thio, C.C., Magdalena, M.M., Jaka, S., Yohanes, S. and Suryadi, I. (2009) Activated Carbon from Durian Shell: Preparation and Characterization. Journal of the Taiwan Institute of Chemical Engineers, 40, 457-462. https://doi.org/10.1016/j.jtice.2008.10.002

[23] Njoku, V., Foo, K., Asif, M. and Hameed, B. (2014) Preparation of Activated Carbons from Rambutan (Nephelium lappaceum) Peel by Microwave Induced $\mathrm{KOH}$ Activation for Acid Yellow 17 Dye Adsorption. Chemical Engineering Journal, 250, 198-204. https://doi.org/10.1016/j.cej.2014.03.115

[24] Li, K., Tian, S., Jiang, J., Wang, J., Chen, X. and Yan, F. (2016) Pine Cone Shell Based Activated Carbon Used for $\mathrm{CO}_{2}$ Adsorption. Journal of Materials Chemistry A, 4, 5223-5234. https://doi.org/10.1039/C5TA09908K

[25] Okman, I., Selhan, K., Tay, T. and Murat, E. (2014) Activated Carbons from Grape Seeds by Chemical Activation with Potassium Carbonate and Potassium Hydroxide. Applied Surface Science, 293, 138-142. https://doi.org/10.1016/j.apsusc.2013.12.117

[26] Omeiza, F.S., Ekwumemgbo, P., Kagbu, J. and Israel, K.O. (2011) Analysis and Production of Activated Carbon from Carica Papaya Seed by Chemical Activation. Chemical Technology: An Indian Journal, 6, 31-35.

[27] Aaron, D. and Annie, C. (2019) Production and Optimization of NaCl Activated Carbon from Mango Seed Using Response Surface Methodology. Biomass Conversion and Biorefinery, 9, 421-431. https://doi.org/10.1007/s13399-018-0361-3

[28] https://www.grandviewresearch.com/industry-analysis/activated-carbon-market

[29] https://ihsmarkit.com/products/activated-carbon-chemical-economics-handbook.html 
[30] Kim, Y.J., Hu, J., Lee, S.J. and You, B.H. (2010) Mechanical Properties of Fiber Reinforced Lightweight Concrete Containing Surfactant. Advances in Civil Engineering, 2010, Article ID: 549642. https://doi.org/10.1155/2010/549642

[31] Mannan, M. and Ganapathy, C. (2001) Mix Design for Oil Palm Shell Concrete. Cement and Concrete Research, 31, 1323-1325. https://doi.org/10.1016/S0008-8846(01)00585-3

[32] Corinaldesi, V. (2011) Structural Concrete Prepared with Coarse Recycled Concrete Aggregate: From Investigation to Design. Advances in Civil Engineering, 2011, Article ID: 283984. https://doi.org/10.1155/2011/283984

[33] Mirza, S.A. (2011) Examination of Strength Modeling Reliability of Physical Tests on Structural Concrete Columns. Advances in Civil Engineering, 2011, Article ID: 428367. https://doi.org/10.1155/2011/428367

[34] Khan, M.M.H., Guong Wei, L., Deepak, T.J. and Nair, S. (2016) Use of Oil Palm Shell as Replacement of Coarse Aggregate for Investigating Properties of Concrete. International Journal of Applied Engineering Research, 11, 2379-2383.

[35] Talukdar, S., Islam, S.T. and Banthia, N. (2011) Development of a Lightweight Low-Carbon Footprint Concrete Containing Recycled Waste Materials. Advances in Civil Engineering, 2011, Article ID: 594270. https://doi.org/10.1155/2011/594270

[36] Mannan, M.A., Alexander, J., Ganapathy, C. and Teo, D.C.L. (2006) Quality Improvement of Oil Palm Shell (OPS) as Coarse Aggregate in Lightweight Concrete. Building and Environment, 41, 1239-1242. https://doi.org/10.1016/j.buildenv.2005.05.018

[37] Harimi, D.J., Ming, C.C. and Narayanan, S.P. (2007) Effect of Ventilation on Indoor Temperature in Malaysia. 2007 Conference on Sustainable Building Southeast Asia, Malaysia, 5-7 November 2007, 149-156.

[38] Shafigh, P., Zamin, J. and Hilmi, M. (2011) Oil Palm Shell as a Lightweight Aggregate for Production High Strength Lightweight Concrete. Construction and Building Materials, 25, 1848-1853. https://doi.org/10.1016/j.conbuildmat.2010.11.075

[39] Mannan, M. and Ganapathy, C. (2004) Concrete from an Agricultural Waste-Oil Palm Shell (OPS). Building and Environment, 39, 441-448. https://doi.org/10.1016/j.buildenv.2003.10.007

[40] Okafor, F.O. (1988) Palm Kernel Shell as a Lightweight Aggregate for Concrete. Cement and Concrete Research, 18, 901-910. https://doi.org/10.1016/0008-8846(88)90026-9

[41] Okpala, D. (1990) Palm Kernel Shell as a Lightweight Aggregate in Concrete. Building and Environment, 25, 291-296. https://doi.org/10.1016/0360-1323(90)90002-9

[42] Basri, H., Mannan, M. and Zain, M. (1999) Concrete Using Waste Oil Palm Shells as Aggregate. Cement and concrete Research, 29, 619-622. https://doi.org/10.1016/S0008-8846(98)00233-6

[43] Keat, T.L., Lee, C.L., Abdul, R.M. and Norhusna, M.N. (2013) Synthesis of Activated Carbon from Lignocellulosic Biomass and Its Applications in Air Pollution Control: A Review. Journal of Environmental Chemical Engineering, 1, 658-666. https://doi.org/10.1016/j.jece.2013.09.017

[44] Soheir, K., Mona, S., Nady, F. and Amina, A. (2014) Effect of Physical and Chemical Activation on the Removal of Hexavalent Chromium Ions Using Palm Tree Branches. ISRN Environmental Chemistry, 2014, 1-10. https://doi.org/10.1155/2014/705069

[45] Enaime, G., Ennaciri, K., Ounas, A., Bacaoui, A., Seffen, M., Selmi, T. and Yaacoubi, 
A. (2017) Preparation and Characterization of Activated Carbons from Olive Wastes by Physical and Chemical Activation: Application to Indigo Carmine Adsorption. Journal of Materials and Environmental Sciences, 8, 4125-4137

[46] Atef, S.A. (2016) Physical, Chemical and Adsorptive Characteristics of Local Oak Sawdust Based Activated Carbons. Asian Journal of Scientific Research, 9, 45-56. https://doi.org/10.3923/ajsr.2016.45.56

[47] Saad, M.J., Chin, H.C., Sarani, Z., Sajab, M.S., Sufian, M., Hariz, A.R. and Siew, X.C. (2019) Physical and Chemical Properties of the Rice Straw Activated Carbon Produced from Carbonization and $\mathrm{KOH}$ Activation Process. Sains Malaysiana, 48, 385-391. https://doi.org/10.17576/jsm-2019-4802-16

[48] Jian, G., Song, Y., Ji, X., Cai, L., Ji, L., Wang, Y., Zhang, H. and Song, W. (2019) Preparation and Characterization of Nanoporous Activated Carbon Derived from Prawn Shell and Its Application for Removal of Heavy Metal Ions. Materials, 12, E241.

[49] Hasbullah, T., Rosli, N.A. and Selaman, O.S. (2014) Removal of Methylene Blue from Aqueous Solutions Using Chemical Activated Carbon Prepared from Jackfruit (Artocarpus Heterophyllus) Peel Waste. UNIMAS e-Journal of Civil Engineering, 5, 34-38. https://doi.org/10.33736/jcest.131.2014

[50] Unal, G., Osman, U., Guney, G. and Yuksel, B. (2016) Adsorption of Cationic Dyes on Activated Carbon Obtained from Waste Elaeagnus Stone. Adsorption Science \& Technology, 34, 512-525. https://doi.org/10.1177/0263617416669727

[51] Dipa, D., Debi, P.S. and Meikap, B.C. (2015) Preparation of Activated Carbon from Green Coconut Shell and Its Characterization. Journal of Chemical Engineering \& Process Technology, 6, Article ID: 1000248.

[52] Roozbeh, H.H., Arash, A., Wan, M. and Sahu, J.N. (2013) Preparation and Characterization of Activated Carbon from Apple Waste by Microwave Assisted Phosphoric Acid Activation: Application in Methylene Blue Adsorption. BioResources, 8, 2950-2966. https://doi.org/10.15376/biores.8.2.2950-2966

[53] Loriane, A., Liana, A. and Gilmar, P. (2017) Preparation of Activated Carbon from Orange Peel and Its Application for Phenol Removal. International Journal of Engineering Research \& Science, 3, 122-129.

[54] Jervis, S., Yugo, W.N. and Hizba, I. (2018) Preparation of Activated Carbon from Banana Peel Waste as Adsorbent for Motor Vehicle Exhaust Emissions. E3S Web of Conferences, 67, Article ID: 03020. https://doi.org/10.1051/e3sconf/20186703020

[55] Zhao, W., Luo, L., Chen, T., Li, Z., Zhang, Z. and Fan, M. (2018) Activated Carbons from Oil Palm Shell for Hydrogen Storage. IOP Conference Series: Materials Science and Engineering, 368, Article ID: 012031. https://doi.org/10.1088/1757-899X/368/1/012031

[56] Gulnaziya, I., Mohamed, K.A. and Nik, M.S. (2010) Study on Palm Shell Activated Carbon Adsorption Capacity to Remove Copper Ions from Aqueous Solutions. Desalination, 262, 94-98. https://doi.org/10.1016/j.desal.2010.05.051

[57] Muzakkir, M.Z., Mohd, A. and Nor, A. (2015) Impregnation of Magnetic Particles on Oil Palm Shell Activated Carbon for Removal of Heavy Metal Ions from Aqueous Solution. Jurnal Teknologi, 72, 7-11. https://doi.org/10.11113/jt.v72.3278

[58] Saifuddin, M.N. and Kumaran, P. (2005) Removal of Heavy Metal from Industrial Wastewater Using Chitosan Coated Oil Palm Shell Charcoal. Electronic Journal of Biotechnology, 8, 43-53. https://doi.org/10.2225/vol8-issue1-fulltext-7

[59] Hector, R., Monica, Z., Liliana, G., Rocio, S. and Juan, C. (2015) Production and 
Characterization of Activated Carbon from Oil Palm Shell for Carboxylic Acid Adsorption. Oriental Journal of Chemistry, 31, 753-762.

https://doi.org/10.13005/ojc/310217

[60] Lua, A.C. and Guo, J. (2001) Microporous Oil Palm Shell Activated Carbon Prepared by Physical Activation for Gas Phase Adsorption. Langmuir, 17, 7112-7117. https://doi.org/10.1021/la010290c

[61] Sheila, N.P. and Mahmud, S. (2018) Hydrogen Recovery from Hydrogen Methane Gas Mixture Utilized by Palm Shell Based Bioadsorbent Activated Carbon. Materials Science Forum, 929, 128-135.

https://doi.org/10.4028/www.scientific.net/MSF.929.128

[62] Arash, A.N., Wan, M.A. and Farouq, S.M. (2010) Using Granular Activated Carbon Prepared from Oil Palm Shell by $\mathrm{ZnCl}_{2}$ and Physical Activation for Methane Adsorption. Journal of Analytical and Applied Pyrolysis, 89, 197-203.

https://doi.org/10.1016/j.jaap.2010.08.006

[63] Izan, I.M., Nurul, K.M. and Rajan, J. (2019) Conversion of Oil Palm Kernel Shell Biomass to Activated Carbon for Supercapacitor Electrode Application. Waste and Biomass Valorization, 10, 1731-1740. https://doi.org/10.1007/s12649-018-0196-y

[64] Hendriansyah, R., Tirto, P., Pramujo, W., Nurdin, I. and Hary, D. (2018) Manufacturing Carbon Material by Carbonization of Cellulosic Palm Oil Waste for Supercapacitor Material. Regional Symposium on Chemical Engineering 2017, Semarang, 15-16 November 2017. https://doi.org/10.1051/matecconf/201815603018

[65] Tan, I., Ahmad, A. and Hameed, B. (2008) Enhancement of Basic Dye Adsorption Uptake from Aqueous Solutions Using Chemically Modified Oil Palm Shell Activated Carbon. Colloids and Surfaces A: Physicochemical and Engineering Aspects, 318, 88-96. https://doi.org/10.1016/j.colsurfa.2007.12.018

[66] Mook, W.T., Aroua, M.K. and Malgorzata, S. (2016) Palm Shell Based Activated Carbon for Removing Reactive Black 5 Dye: Equilibrium and Kinetics Studies. BioResources, 11, 1432-1447. https://doi.org/10.15376/biores.11.1.1432-1447 